American Journal of Agricultural and Biological Sciences 7 (2): 207-216, 2012

ISSN 1557-4989

(C) 2012 Science Publications

\title{
Petroleum Hydrocarbon Pollution of Mangrove Swamps: The Promises of Remediation by Enhanced Natural Attenuation
}

\author{
${ }^{1}$ Orji, F.A., ${ }^{2}$ A.A. Ibiene and ${ }^{3}$ O.C. Ugbogu \\ ${ }^{1}$ Department of Biotechnology, Enzymes and Genetics Division, \\ Federal Institute of Industrial Research, Oshodi, PMB 21023, Ikeja, Lagos, Nigeria \\ ${ }^{2}$ Department of Microbiology, Faculty of Science, \\ University of Port Harcourt, PMB 5323, Port Harcourt, Nigeria \\ ${ }^{3}$ Department of Microbiology, Faculty of Biological and Physical Sciences, \\ Abia State University, PMB 2000, Uturu, Abia State, Nigeria
}

\begin{abstract}
Problem statement: The Remediation by Enhanced Natural Attenuation (RENA) is currently being used as a cleanup technology in polluted environments in the Niger Delta and other parts of the globe. The effectiveness of RENA as a remediation technology in the most recent time has been challenged by few authorities. The deleterious effects of pollutants on the environment have led to increased awareness and vigilance against contamination of the Niger Delta environment. Bio remediation which has been defined as biological response to environmental abuse has continued to receive research attentions across the globe. This study addresses issues against the RENA and recommended ways forward. Approach: The review paper studied published articles and Oil companies routine practices of managing petroleum hydrocarbon polluted Environments including mangrove swamps from 1970 till date. The Remediation by Enhanced Natural Attenuation (RENA) is currently being used as a cleanup technology in polluted environments in the Niger Delta including mangrove ecosystems. Results: The study made inputs on the controversial issues around RENA technology and recommended certain ways forward. This revision also reported the ways of managing the concerns raised against RENA. Conclusion/Recommendations: Oil firms, remediation contractors and consultants using this RENA approach should employ strict monitoring during the process and also adhere strictly to standard practices and the mitigation measures for all the cases against RENA as documented in this review study. This is to ensure the achievement of Sustainable Development.
\end{abstract}

Key words: Remediation by Enhanced Natural Attenuation (RENA), Polycyclic Aromatic Hydrocarbons (PAHs), Niger Delta Development Commission (NDDC), Total Petroleum Hydrocarbon (TPH), Plant Growth Promoting Bacteria (PGPB)

\section{INTRODUCTION}

The Niger delta formation: The Niger Delta is the product of both fluvial and marine sediment build-up for the upper cretaceous period, some $50 \mathrm{~m}$ years ago. Over time, up to 12,000 meters of shallow marine sediments and deltaic sediments have accumulated, contributed mainly by the Niger River and its tributaries (Nwilo and Badejo, 2001). The main upper geological layers consist of Benin Formation, Agbada Formation and Akata Formation. The Benin Formation is comprised of multiple layers of clay, sand, conglomerate, peat and/or lignite, all of variable thickness and texture and covered by overburden soil.
Clay beds are discontinuous and groundwater is therefore present both as localized aquifers and in hydraulically interconnected aquifers. The ground characteristics are consistent with deltaic environments, where erosion and deposition of sediments constantly shift the course of channels, tributaries and creeks (Nwilo and Badejo, 2001).

The Niger delta vegetation: The coastal area comprises three vegetation zones: (i) beach ridge zone, (ii) saltwater zone and (iii) freshwater zone. The beach ridge zone is vegetated by mangroves on the tidal flats and by swamp trees, palms and shrubs on the sand ridges. The saltwater zone is mainly vegetated by red

Corresponding Author: Orji, F.A. Department of Biotechnology, Enzymes and Genetics Division,

Federal Institute of Industrial Research, Oshodi, PMB 21023, Ikeja, Lagos, Nigeria

Tel: +2348034914979 
mangrove (Rhizophora mangle). The coastal plain and freshwater zone is vegetated by forest tree species and oil palm. The Niger River floodplains are covered by rainforest trees, oil palm, raffia palms, shrubs, lianas, ferns and floating grasses and reeds. Mangroves have traditionally provided a variety of ecosystem services and products to the community, including fishing grounds, timber for housing and fuel wood. Tree and shrub cover remains important in uncultivated areas. Other non-timber forest products which are important, especially for poorer households, include grass cutters, bamboo for staking of yam (edible perennial herbaceous vines), medicinal plants, vegetables, fruits and snails, turtles (IPIECA, 1993).

General Overview of the mangrove forests and swamps: Mangrove forests are among the world's most productive ecosystems. They enrich coastal waters, yield commercial forest products, protect coastlines and support commercial fisheries.

However, mangroves exist under conditions of high salinity, extreme tides, strong winds, high temperatures and muddy, anaerobic soils. There may be no other group of plants with such highly developed morphological, biological, ecological and physiological adaptations to extreme conditions.

Mangroves and mangrove ecosystems have been studied extensively but remain poorly understood. With continuing degradation and destruction of mangroves, there is a critical need to understand them better. Aspects of mangrove biology have been treated in recent reviews. Tomlinson (1986) described the basic botany of mangroves. Snedaker and Snedaker (1984) reviewed mangrove research and made recommendations for further research. An overview of tropical mangrove community ecology, based primarily on Australian work, can be found in Robertson and Alongi (1995). Li and Lee (1997) reviewed much of the Chinese mangrove literature published between 1950 and 1995. Bertness et al. (2001) have also published a general review of mangrove ecology.

As researchers continue to discover important facts about mangroves and the role they play in the global ecosystem, the volume of published information has grown enormously and increasing numbers of workers are drawn to these unique environments. Thus, there is a need for periodic reviews of the rapidly expanding literature. In this review, Literature on mangrove ecosystems including pollution, remediation on the Mangrove swamps between 1970 and 2011 were consulted.

Microbial diversity of mangrove forests and swamps: The importance of microbial generated detritus in mangrove areas that act as the major substrate for bacterial growth in mangrove ecosystem was outlined in a conceptual model by Bano et al. (1997). The abundance and activities of bacteria are controlled by various physical and chemical factors such as tannins, leached from mangrove ecosystem.

Increasing tannin concentration is associated with decreasing bacterial counts. Thus, tannins play a role not only keeping the bacterial count flow but also by keeping the harmful activities of virulent pathogens down (Kathiresan et al., 1996). The bacteria isolated and associated with mangrove swamps include: nitrogen fixing bacteria, sulphate reducing bacteria, photosynthetic anoxygenic bacteria.

Mangrove areas are homes of a group of fungi called mangicolous fungi (Hennig, 2009). These organisms are virtually for nutrient cycling in these habitats. These fungi are able to synthesize all the necessary enzymes to degrade lignin, cellulose and other plant components. Few scholars have listed about 120 species of fungi from different mangrove swamps from around the world. These include: 87 Ascomycetes, 31 Deutromycetes and 2 Basidiomycetes. About 48 fungal species of fungi have been reported to exist. Actinomycetes play important role in natural ecosystems and they are also profiling producers of antibiotics, antitumor agents, enzymes inhibitors and immunomodifiers which have been widely applied in the industries. The mangrove environment is a potent source of antibiotic-producing actinomycetes (Hennig, 2009). An antibiotic compound-beta unsaturated gamma-lactone from Streptomycetes grisebrunneus, showing wide range antimicrobial activities has been isolated and identified from the mangrove swamps. Besides, this Streptomyces produces cells that degrade cellulolytic waste materials (Hennig, 2009).

The ecological benefits of the mangrove swamps: Mangrove green belts are known to offer some protection against destructive ocean events, such as tsunamis and tropical cyclones, but they have not always been valued for this function. Plant Growth Promoting Bacteria (PGPB) speed up the development of mangrove plant lets for reforestation of damaged areas or even to create artificial mangrove wetlands out of the wastelands. These PGPB promote the plant growth by mechanisms such as $\mathrm{N}_{2}$ fixation, phytohormone production, siderophore synthesis and biocontrol of phytopathogens (Kloeppar et al., 1980; Glick, 1995). These benefits of the mangrove swamp are one of the reasons why such biodiversified environment must be protected from destruction as a result of crude oil pollution (IPIECA, 1993). 
Economical benefits of mangrove swamps: Mangroves swamps are highly productive bio types and as such have a vibrant and endemic wildlife. The mangrove swamps accommodate mangrove forests and the salt marshes connected to them provide food and a home for fish, shellfish, molluscs, wild fowl and threatened marine mammals. Most of these species are endemic to the mangroves, meaning they cannot live in any other place. Most of the endemic species are an enormous variety of crabs. In addition, many other species need the mangroves during periods of their life. Ducks, Geese and other wild birds stop over at coastal wetlands during migration. Flounder and bluefish use the marshes as nurseries, winter quarters and occasional feeding grounds. The mangrove swamps further offer nursery and breeding grounds for freshwaters and marine life-especially shrimps.

The manatees may serve as another example of many endangered species of the African mangroves. The West African manatees (also called sea cows and sirens, Trichechus senegalensis) live in rivers, bays, estuaries and coastal areas, (Hennig, 2009). Although they are marine animals, the manatees are related to neither whales, walrus nor dolphins. Adult manatees range in length from $2.5-4.5 \mathrm{~m}$ and may reach nearly $700 \mathrm{~kg}^{-1}$ in weight. Adult manatees have no natural enemies but in some areas they are heavily hunted for meat, hides and oil. Apart from the manatees, the most characteristic species of the mangroves are the sea birds (Hennig, 2009). Mangrove swamps trees grow well within their special conditions-where no other trees could be planted and like the tropical forests, they produce a lot of leaves and other organic matter, detritus. Instead of accumulating in the soil, the leaves fall in the water, where they rot and provide food for microbes and planktons. This gain is excellent fish fodder in the areas near mangroves swamp have proven to be a source of food and materials for many coastal people. Crabs, oysters, fish and other seafood are often collected there. Mangrove wood is often collected as firewood and it can also be used as timber for construction. The barks of these trees have tannins and saponins which have craft and medicinal uses (Hennig, 2009). One very important environmental service provided by mangroves is that they also build land or keep it from being washed away. Even in the big cities of the world, mangroves can be important when the city waters run off and pollute the nearby coastal waters. When these waters run into the mangrove swamps, they are normally absorbed by the swamps and used by plants and animals present in the swamp. The swamp filters the waters, making use of the nutrients and also absorbing toxic and leaving clean water (Hennig, 2009).
Biological impacts of oil pollution in mangrove swamps: The adverse effects of oil drilling in or near mangrove swamp shorelines have been widely reported. Oil slicks enter the swamps during high tidal conditions and become deposited on the aerial roots and sediment surface. Conventionally, the mangrove swamps have tendencies to be adversely affected by crude oil production because of known high persistence of oil in low-energy muddy environments (Duke et al., 2000; Odokuma and Dickson, 2003).

Mangroves are killed by heavy or viscous oil that covers the trees breathing pores thereby leading to the loss of oxygen available to the roots of the mangroves. Toxic substances such as Total petroleum hydrocarbons, Polycyclic Aromatic Hydrocarbons (PAHs) can knock off mangroves if they are available in the swamp. It is worthy to note that these two features of mangroves, their aerial root systems alongside their intertidal muddy nature, make them susceptible to the effects of crude oil production. This susceptibility to oiling ensures that crude oil in mangrove swamps persists for a period of time beyond normal (Vandermeulen and Gilfillan, 1985; IPIECA, 1993). It is advisable that biodiversity be incorporated into sensitive maps of the Niger Delta (Gundlach et al., 2001). In other developing countries and developed countries, the mangrove swamps have been beneficial for rearing of shrimps. In Brazil, the mangroves are used for shore protection and are frequently associated with fish farming in a commercial scale (Marciel-Souza et al., 2006). In the Niger Delta, mangrove remains very important to the indigenous people of Nigeria and covers approximately $5,000-8580 \mathrm{~km}^{2}$ of land. The human impact of poor upstream management coupled with the constant pollution of oil has caused five to ten percent of these mangrove forests to disappear. The volatile, quickly penetrating and viscous properties of oil have wiped out large areas of vegetation. In Nigeria, the fishing industry is an essential part of Nigeria's sustainability because it provides much needed protein and nutrients. People living around mangrove swamp rear fishes in mangroves. However, crude oil pollution of the swamp kills fish, thereby threatening the food security and the geopolitical economy of the Niger Delta. Mangrove forests and the salt marshes connected to them provide food and a home for fish, shellfish, wildfowl and threatened marine mammals. Most of these species are endemic to the mangroves. In addition, many other species need the mangroves in the period of their life. These include different kinds of birds. The mangroves are habitats of manatees, (Trichechus senegalensis) where they graze on mangrove shrubs. They are zoologically related to 
elephants and measures about $700 \mathrm{~kg}^{-1}$. The mangrove swamps protect coastal areas from erosion, storm surge, hurricanes, tsunamis (Tomlinson, 1986).

Today, crude oil pollution has been a major threat to the existence of mangrove forests/swamps. Oil exploration, pipeline sabotage has led to increased amounts of crude oil spills in the Niger Delta. Crude oil spills automatically alters the benefits of the mangroves in negative manners. The adverse effects have led to complete loss or disappearance of this ecosystem in the Region. Local and international groups have provided funds and labor to remediate and restore the destroyed mangrove swamps. The government of Nigeria established the Niger Delta Development Commission (NDDC) in 2000 and part of its mandate is to suppress the environmental and ecological impacts of oil exploration in the Niger Delta region. The poor land management upstream from human impacts coupled with oil industry activities and associated pollution of oil has caused land take and mangrove forest clearing, severe fragmentation and damage to the ecosystem. These scenarios have facilitated and provided a venue for a non-native invasive species of palm, Nypa fruticans which is quickly colonizing the mangrove systems and has also decreased biodiversity and ecosystem functions in the Region (Chindah et al., 2007).

The Niger delta mangroves: The Niger delta mangroves cut across some of the Niger Delta States in Nigeria. The Mangroves of the Niger Delta are available in Rivers, Bayelsa, Cross River, Akwa Ibom, Edo States of the Federal Republic of Nigeria. However it is worthy to note categorically that there are Mangrove forests in Non-Niger Delta regions of Nigeria such as Lagos State, Nigeria. Thus, the scope of this review study did cover Mangrove forests that are not in the Niger Delta region. The Niger delta of Nigeria has four main ecological zones; coastal barrier islands, mangrove swamp forests, freshwater swamps and lowland rainforests. These ecological zones are incredibly well-endowed with highest concentrations of biodiversity in addition to supporting the abundant flora and fauna (NDDC, 2004). In the lower delta, within the estuarine limits is located large area of mangrove forests estimated to cover approximately 5,000-8,580 $\mathrm{km}^{-2}$ of mangrove wetland (NDDC, 2004). There are three main mangrove families; (Rhizophoraceae, Avicenniaceae and Combretaceae) comprising (six) 6 species namely: Rhizophora racemosa, Rhizophora mangle, Rhizophora harrisonii, Languncularia racemosa, Avicennia germinans and Conocarpus erectus, Acrostichum aureum and the exotic family Palmae (Arecaceae) Nypa fruticans that is now spreading fast across the Niger Delta (Chindah et al., 2007). The poor land management upstream from human impacts coupled with oil industry activities and associated pollution of oil has caused land take and mangrove forest clearing, severe fragmentation and damage to the ecological zone ecosystem (Chindah et al., 2007). These scenarios have facilitated and provided a venue for a non-native invasive species of palm, Nypa fruticans that have quickly colonized the mangrove system. The shallow root system and poor litter generation potential help to destabilize the normal banks sediment distribution, resulting in declining nutrient processes, poor recruitment potentials, decreases in biodiversity and reducing of ecosystem functions (Chindah et al., 2007).

The objectives of this review is to make information more readily available on the state of the Niger Delta Mangroves, degradation of the Niger Delta Mangrove Swamps and the good promises of Bioremediation on restoration of the polluted Mangroves in the Niger Delta. This review reports mitigation measures of handling or managing the concerns raised by a few authorities against RENA.

The impact of oil on mangrove vegetation in some parts of the Niger Delta including Ogoni land has been disastrous, as was evident to the UNEP team during an early reconnaissance mission along the creeks. Impacts vary from extreme stress to total destruction. In the most impacted areas, only the roots of the mangroves remain, with no stems or leaves. The roots are completely coated in oil, sometimes with a $1 \mathrm{~cm}$ or thicker layer of bituminous substance (Fig. 1).

Implications of petroleum hydrocarbon pollution of
mangrove swamps in the Niger delta: Mangrove ecosystems, together with sea grasses and coral reefs, are among the world's most productive natural ecosystems. They are characterized by a dynamic equilibrium between flooding, erosion and sediment deposition and have adapted to frequent changes in the shoreline. The mangrove trees and bushes are a keystone species of central importance for brackish wetland ecosystems and the terrestrial and aquatic organisms which inhabit them. Consequently, mangroves are not just ecologically significant but are critical to the livelihood and food security of the Niger delta communities. Crude oil pollution has not only reduced productive outputs of the delta mangroves, but has also bio-accumulated in edible sea foods from the mangroves. Bio-accumulation of Total Petroleum Hydrocarbon (TPH) and Polycyclic Aromatic Hydrocarbons (PAH's) (Suni et al., 2007; Ibiene et al., 2011a). 


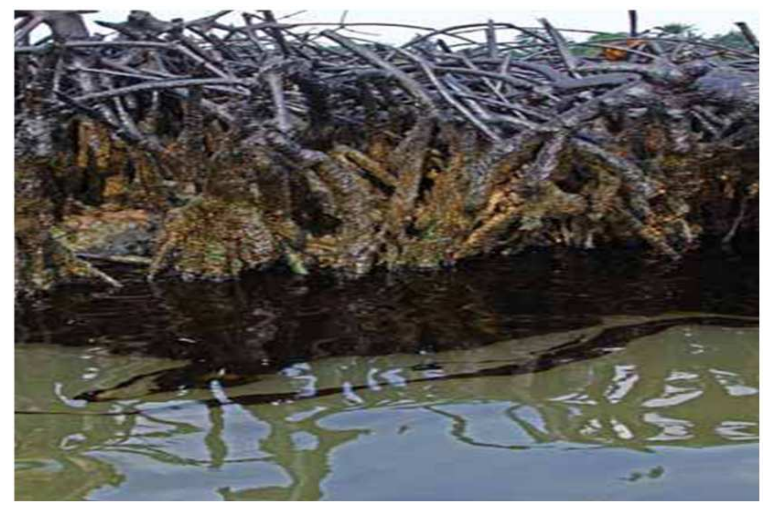

Fig. 1: Mangrove roots heavily coated with a thick layer of bituminous substance in Bonny, SouthSouth, Nigeria

Different levels of heavy metal concentrations have been reported in Nigerian water bodies by several workers. Obire et al. (2003) on Elechi creek, Omoigberale and Ogbeibu (2005) on Osse River, Southern Nigeria. Ogbeibu and Victor (1989) amongst other Nigerian or indigenous scholars have advocated the use of fish and invertebrates as bio-indicators of water quality. A considerable amount of studies has been carried out on the effects of pollution in Nigerian water bodies. Victor and Tetteh (1988) reported a reduction in fish diversity associated with discharge of municipal wastes and industrial pollutants into the Ikpoba River, while Fufeyin (1998) studied heavy metal concentration in some dominant fish in the river and reported that the fish species showed higher mean levels, with variable contamination factor and bioaccumulation quotient among stations. However, the UNDP Report (2011) documented that the concentrations of PAHs in biota were low in all samples in Ogoniland. In fresh fish and seafood, concentrations were below the detection limit for most of the different PAHs. In a few cases, measurable but low levels were found. This investigation showed that the accumulation of hydrocarbons in fish tissue is not a serious health risk in Ogoniland.

\section{MATERIALS AND METHODS}

The review process covered all internet publications from 1970 to date. The search engines used include googles, sciencedirect.com, mama.com, altavista.com.etc. The search words used were: Remediation by enhanced natural attenuation, Environmental degradation, Sustainable Development, Mangrove swamps and Ecology, Biotechnological and ecological benefits of the Mangrove swamps, Crude Oil pollution of the Mnagrove Swamps in the Niger Delta and other parts of the world, The cases against RENA and cases for RENA, UNDP report on Ogoniland, Benefits of RENA technology for the Poluted Mangrove swamps and other environment.

\section{RESULTS}

The concept of Remediation by Enhanced Natural attenuation (RENA): The term "monitored natural attenuation," as used by the EPA, refers to the reliance on natural processes to achieve site-specific remedial objectives. Monitored natural attenuation may be used within the context of a carefully controlled and monitored site cleanup approach. To be considered an acceptable alternative, monitored natural attenuation would be expected to achieve site remedial objectives within a time frame that is reasonable compared to that offered by other more active methods. Monitored natural attenuation is always used in combination with "source control; that is, removal of the source of the contamination as far as practicable USEPA, 1999. Remediation by Enhanced Natural Attenuation (RENA) is a land farming treatment technology for intervention in petroleum hydrocarbon contaminated soils in the Niger Delta regions (Ifeadi and Nwankwo, 1980; Odeyemi and Ogunseitan, 1985; Odu, 1972). RENA is a full-scale bioremediation technology in which contaminated soils, sediments and sludge's, are periodically turned over or tilled into the soil to aerate the waste. Soil conditions are often controlled to increase the rate of contaminant degradation (Odu, 1978; Gradi, 1985). Wilson et al. (2007) demonstrated a lot of success in the use of monitoring natural attenuation for cleaning-up of chlorinated solvents in the environment. Dong et al. (2007) developed a simulation optimization model for remediation of groundwater polluted by chemicals of concerns using natural attenuation process.

Bioremediation process enhances the indigenous bacteria via the addition of oxygen and nutrients to degrade petroleum hydrocarbon to carbon dioxide and water. The actual mechanism involved, which is mediated by microbes, is known as biodegradation (Hamme et al., 2003). The RENA process involves other processes other than bio degradation.

The schematic diagram (Fig. 2) Shows the involvement factors such as evaporation, Dispersion, Spreading, Dissolution, Oxidation, Emulsification and Spreading. At the early onset of the concept of Remediation by enhanced natural attenuation, communities where RENA technology is used sometimes see the technology as a runaway technology by Oil Exploration companies. 


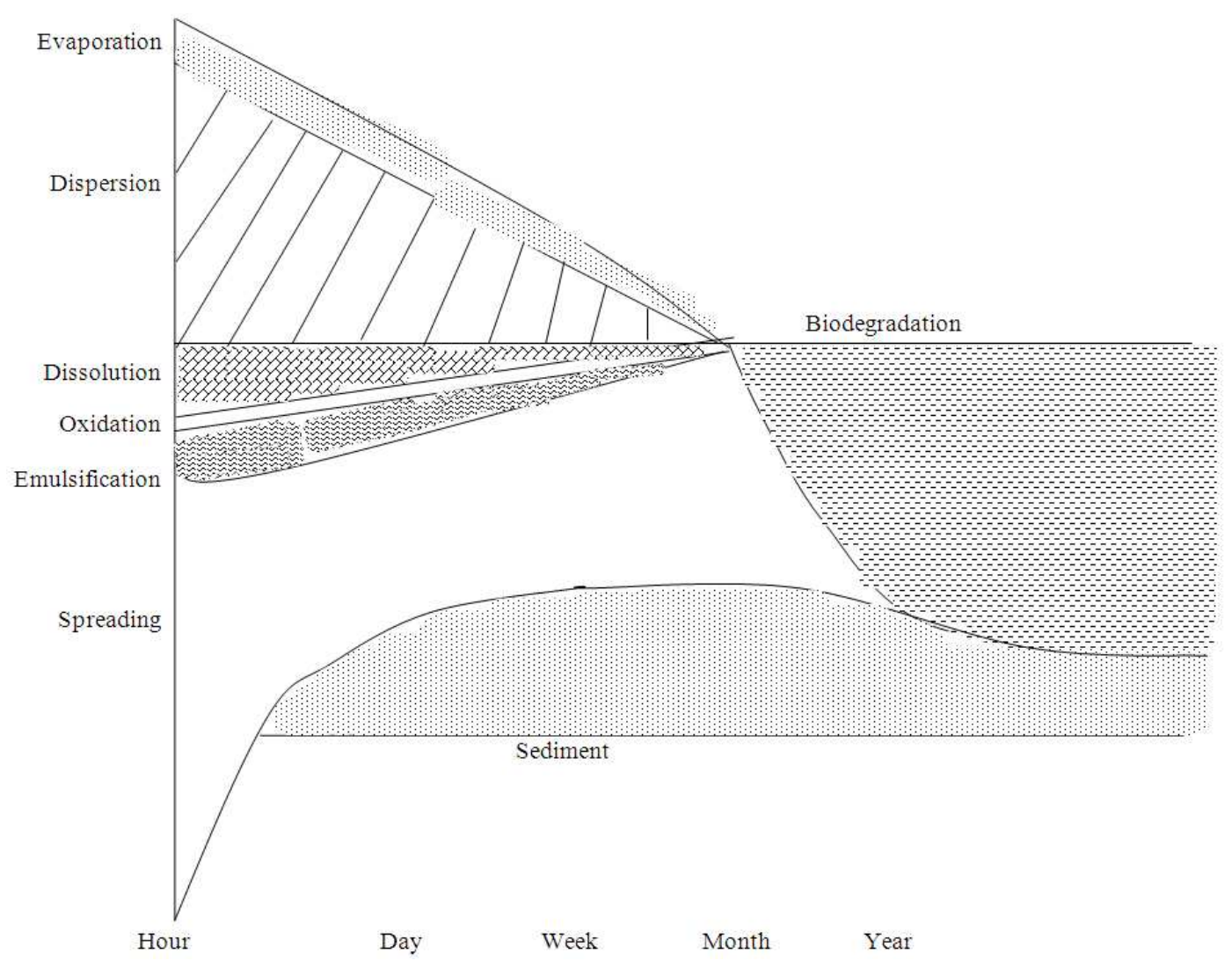

Fig. 2: Schematic representation of oil spill fate in an aquatic medium or polluted environment

However, it is currently used by companies across the globe for remediation of media impacted by Chemicals of Concerns (COC's).

In Nigeria a wide range of research reports of fields that are successfully cleaned-up with RENA exist.

A farmland settlement contaminated with crude oil located in Rumuekpe, Rivers State, Nigeria, was cleaned up using the remediation by enhanced natural attenuation (Ebuehi et al., 2005).

The study in Rumuekpe reported a success story of TPH degradation/decrease during the bioremediation process. Okoro, 2010 reported the use of the same process to remediate Crude-oil polluted Mangrove swamps in the Escravos, Niger Delta.

Ibiene et al. (2011b), in a 90 days study, investigated bioremediation in crude oil polluted soil just by remediation by natural attenuation without nutrient enhancement. The study was done in Aluu and Mogho communities of Rivers State, Nigeria. The soil samples were never amended but the study reported Total Hydrocarbon Content (THC) decrease from 60604934 and 5080-3627 $\mathrm{Mg} \mathrm{kg}^{-1}$ for Mogho and Aluu crude oil polluted soils respectively. In both polluted soils, decrease in limiting nutrients was observed.

The RENA process in the mangrove swamps will involve:

Stump removal: The mangrove trees can respond to the toxicity of the crude-oil, by the disappearance of the big storms. The stumps of hanging roots are left behind in the sediment. Thus an effective RENA will begin action by de-stumping the mangrove fields to be remitted. This action is usually for Mangrove swamps which must be re-habilitated thereafter remediation (Table 1).

Baseline soil characterization: The baseline data acquisition is an indispensable approach to bioremediation. The data to be collected include microbiological and physico-chemical properties of the polluted soil. The baseline microbiological properties will include total cultural heterotrophic bacteria and fungi count, total cultural hydrocarbon utilizing bacterial and fungal counts. Enzyme studies such as an assay for lipase, polyphenol oxidases, Soil dehydrogenase and catalase are seemingly indispensable. 
Am. J. Agri. \& Biol. Sci., 7 (2): 207-216, 2012

Table 1: Summary of the cases against RENA and the way forward

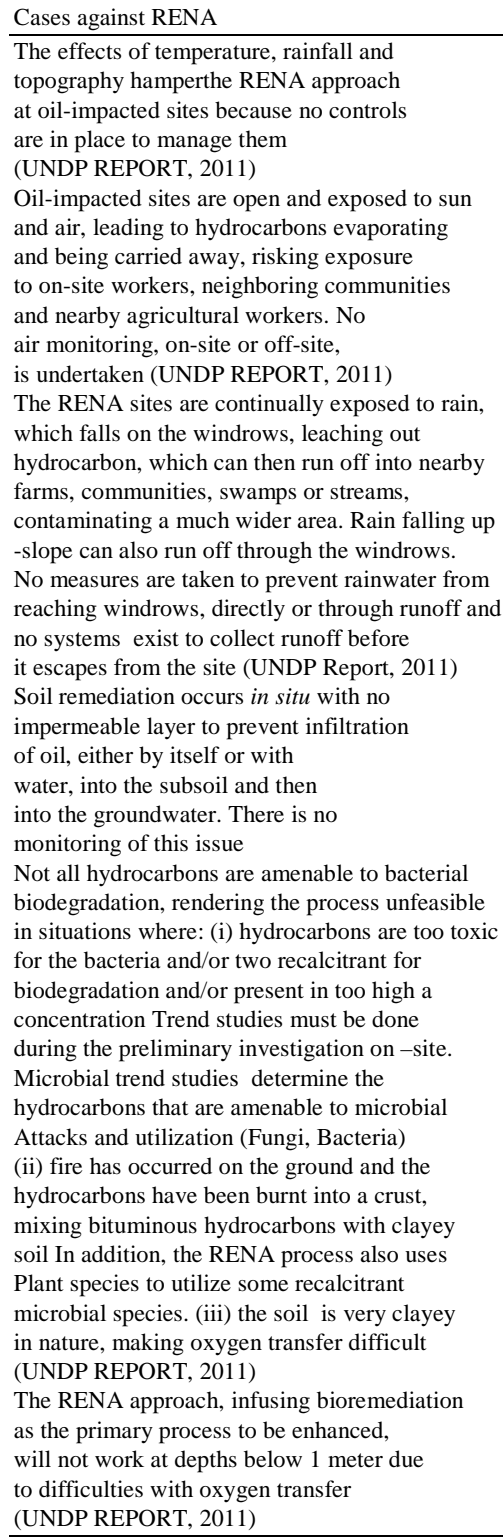

The enzyme studies are an integral aspect of the biophysical studies. The physico-chemical properties will include parameters such as dissolved oxygen, Redox potentials, COD, BOD, percentage total organic carbon, Nitrate and phosphate concentrations, pollution levels (Total petroleum hydrocarbon, Total hydrocarbon Content). Remediation contractors and consultants are advised to include heavy metals assay in the baseline data acquisition.

It's worthy to note that the conceptual site modelling is necessary before commencement of bioremediation through the RENA process. This will enable the experts to determine Soil texture profiles,

\author{
Measures for Mitigation \\ the topography of the impacted medium. The mitigation measures for the stated measures \\ must be documented in a Term of Reference (ToR) Preceding remediation. This should be
}

a ver, companies should be able to accommodate air and Rainwater monitoring within the site RENA is applied. The parameters to be monitored in the air and ground water among others This is a site-specific problem. There should be a system developed through the conceptual Site modelling to monitor whether this hydrocarbon run-off phenomenon happens on a site. If the possibility

The first response to Oil spill in a practical and ideal system after Oil spill volume assessment is Crude oil recovery. The recovery is a bold step against infiltration of Oil. However, for the avoidance of doubts, round water monitoring during the process is quite indispensable. The monitoring of ground water Chromium. These biophysical data should be incorporated into the ToR preceding the Remediation. These data of course will be compared with baseline data obtained during the Environmental Impact studies. 列 chection and maintenance of Microbial cultures with specificity of utilization of different groups of icrobes among other mandates. Again, if the environment is clayey, there is a need for the introduction

The RENA process should involve regular tilling, turning of the polluted soil/ sediments which have already being amended. The tillage should also go beyond $4 \mathrm{~m}$. This will enhance Oil penetration. Research Scholars in Environmental bioremediation could focus their research attentions on the development of cost effective and sustainable oxygen release substances for bioremediation
Soil types, Water holding capacity of the soil, Ground water levels and tables, distances of structures and facilities to themselves and to the polluted area. Information on Conceptual site modelling will enable the Remediation team to take good decision on the method of bioremediation to undertake (either Ex-situ or In-situ bioremediation). Conceptual site modelling gives a road map of the impacted sites and helps to address the issues on risks under the Umbrella of Risk based Philosophy (PBP). The risk Based philosophy involves the Risk Based Corrective Action (RBCA) which studies risk based on a line of Source-Pathwayand Receptors/targets. 
Soil tillage: Bioremediation as a natural process is best achieved through aerobic process. The aerobic biodegradation ensures the complete breakdown of Pollutants (Petroleum hydrocarbon) into Carbon (iv) oxide whereas the anaerobic biodegradation of petroleum hydrocarbon will lead to partial degradation resulting in formation of intermediates that are of environmental concerns. Intermediates such as Mercaptens may possibly transform into a substance with higher carcinogenic potentials. Therefore, in Mangrove sediment especially at the supra-tidal regions where the Mangrove trees are anchored, tillage is of great importance because of its ability to provide molecular oxygen for complete biodegradation of pollutants. It increases the surface area of sediment for atmospheric oxygen uptake and brings up buried oil to the water-sediment interface where microbial actions are optimum. This leads to tidal washout of the oil and enhances photo oxidation when the mudflat is exposed during low tide. It also enhances volatilization in the case of recent spills. Of course, photo-oxidation and volatilization as integral aspects of RENA have their impacts on Crude-oil at the early stage of the RENA process.

Fertilizer application: Coastal marshes are considered high nutrient wetlands, but in practice, the levels of the limiting nutrients are not enough to drive the bioremediation. As earlier stated, the levels of the limiting nutrients and exchange ions are to be ascertained from the baseline analyses. Information on the concentrations of limiting nutrients and exchange ions will determine the amount of fertilizers to be embedded into the polluted Mangrove swamps.

Venosa et al. (1996) reported that the threshold concentration range for optimal hydrocarbon biodegradation on marine shorelines is around 2-10 mg $\mathrm{N}^{-1}$ based on field experiences on sandy beaches. But it is worthy to note that amount of fertilizer be applied depend strictly on the levels/concentrations of the pollutants and limiting nutrients. Thus, baseline studies will go a long way to enable field scientists to determine the amount of fertilizers to incorporate into the polluted media. Remediation experts are advised to regularly to embark on preliminary field scale studies to determine the amount of fertilizers to be added. During the preliminary cleanup, different plots are established such that each plot will not interfere with other plots. Plots are thereafter treated with different amounts of fertilizers. However, the control plot should not be treated. This should be followed by monitoring to determine the plot with optimum loss of Total Petroleum Hydrocarbons (TPH). The concentration of the fertilizer in the plot with optimum loss of TPH is referred to as the optimum fertilizer concentration and it is used for the Real-Scale/main bioremediation after proper calculations, inductive extrapolations and modelling. It is recommended that oleophilic fertilizer be in granulated forms to ensure a slow release of nutrients into the polluted sediments. This method of fertilizer application is cost effective and it is recommended for Mangrove swamps, since washout due to tidal activity alone is relatively high.

Monitoring of remediation: The monitoring process is to begin about five months thereafter amendment of polluted sites. The monitoring process will involve the use of microbiological properties which will include total cultural heterotrophic bacteria and fungi counts, total cultural hydrocarbon utilizing bacterial and fungal counts and enzymes assays. The physicochemical properties to be monitored will include parameters such as dissolved oxygen, COD, BOD, percentage total organic carbon, Nitrate and phosphate concentrations, Redox potential, pollution levels (Total petroleum hydrocarbon, Total hydrocarbon Content). Monitoring as a process should not only be to ascertain the reduction of pollutant below or within regulatory limits but also to ensure that the pollutants during the course of remediation have not impacted on ground water and Air Quality. In view of this, Groundwater and Air quality evaluation must be carried out in line with other studies on the impacted medium under remediation.

\section{CONCLUSION}

The three legged Sustainable development is comprised of social performance, Societal Economics and the Environment. The Niger Delta Mangrove swamps are often exposed to crude oil spill mainly as a result of pipeline vandalization among other causes. The conventional dogma of sustainable Development states that development must not be impeded and the Environment must not also be degraded. This review on the promises of RENA as a cleanup technology reported a lot of advantages the RENA technology possesses. RENA technology is rather friendly with respect to our Environment and should not be seen as a runaway approach.

However, Oil firms, remediation contractors and Consultants using this RENA approach should employ strict monitoring during the process and also adhere strictly to standard practices and the mitigation measures for all the cases against RENA as documented in this review study. 


\section{REFERENCES}

Bano, N., M.U. Nisa, N. Khan, M. Saleem, P.J. Harrison and S.I. Ahmed et al., 1997. Significance of bacteria in the flux of organic matter in the tidal creeks of the mangrove ecosystem of the River Delta, Pakistan. Marine Ecol. Progressive Series, 157: 1-12.

Bertness, M.D. S.D. Gaines and M.E. Hay, 2001. Marine Community Ecology. 1st Edn., Sinauer Publishers, Sunderland, ISBN-10: 0878930574, pp: 550.

Chindah, A.C., S.A. Braide, J. Amakiri and J.O. Onokurhefe, 2007. Effect of crude oil on the development of mangrove (Rhizophora mangle L.) Seedlings from Niger Delta, Nigeria. Estud. Biol., 7: 181-194.

Dong, K.P., K. Nak-Youl and L. Kong-Kun, 2007. Optimal groundwater remediation design considering the effects of natural attenuation processes: pumping strategy with enhancednatural-attenuation. Geosci. J., 11: 377-385.

Duke, N.C., K.A. Burns, R.P.J. Swannell, O. Dalhans and R.J. Rubb, 2000. Dispersant use and a bioremediation strategy as alternate means of reducing the impacts of large oil spills on mangroves: the Gladstone field trials. Marine Pollu. Bull., 41: 403-412. DOI: 10.1016/S0025326X (00)00133-8

Ebuehi, O.A.T., I.B. Abibo, P.D. Shekwolo, K.I. Sigismund and A. Adoki et al., 2005. Remediation of crude oil contaminated soil by enhanced natural attenuation technique. J. Applied Environ. Manage., 9: 103-106.

Fufeyin, P.T., 1998. Heavy metal levels in some dominant fish in Ikpoba Reservoir. Edo State, Nigeria. Environ. Rev., 2: 61-69.

Glick, B.R., 1995. The enhancement of plant growth by free-living bacteria. Canadian J. Microbe., 41: 109117.

Gradi, P.C., 1985. Biodegradation: Its management and microbiology basis. Biotech. Bio-Eng., 27: 660674.

Gundlach, E.R., V.O. Imevbore, B. Witherspoon and J. Ainodion, 2001. Incorporating biodiversity into sensitivity maps of the Niger River Delta. Proceedings of the International Oil Spill Conference, (IOSC' 01), pp: 391-397.

Hamme, J.D.V., A. Singh and O.P. Ward, 2003. Recent advances in petroleum microbiology. Microbiol. Mol. Biol. Rev., 67: 503-549. DOI: 10.1128/MMBR.67.4.503-549.2003
Hennig, R.C., 2009. The mangroves, an undervalued ecosystem. Afrol News.

Ibiene, A.A., F.A. Orji and E.C. Orji-Nwosu, 2011 b. Microbial population dynamics in crude oilpolluted soils in the Niger Delta. Nigerian J. Agric. Food Environ., 7: 8-13.

Ibiene, A.A., F.A. Orji, C.O. Ezidi and C.L. Ngwobia, 2011a. Bioremediation of hydrocarbon contaminated soil using spent mushroom compost and other organic wastes. Nigerian J. Agric. Food Environ., 7: 1-7

Ifeadi, C.N. and J. Nwankwo, 1980. Oil spill incidents in Nigeria petroleum industry. Critical Anal. Napetcor, 8: 11-45.

IPIECA, 1993. Biological impacts of oil pollution: Mangroves. Proceedings of the IPIECA, International Petroleum Industry Environmental Conservation Association, (IPIECA' 90), London

Kathiresan, K., P. Moorthy and S. Ravikumar, 1996. A note on the influence of salinity and $\mathrm{pH}$ on rooting of Rhizophora mucronata Lamk. Seedlings. Indian Forester, 122: 763-764.

Kloeppar, J.W., J. Leong, M. Teintze and M.N. Schroth, 1980. Enhanced plant growth by siderophones produced by plant growth promoting Rhizobacteria. Nature, 286: 885-886.

Li, M.S. and S.Y. Lee, 1997. Mangroves of China: A brief review. Forest Ecology Manage., 96: 241259. DOI: 10.1016/S0378-1127 (97)00054-6

Marciel-Souza, M.C., A. Macrae, A.G.T. Volpon, P.S. Ferreira and L.C.M. Mendonca-Hagler, 2006. Chemical and microbiological characterization of mangrove sediments after oil spill in Guarnabara bay, RJ, Brazil. Brazilian J. Microbiol., 37: 1-8.

NDDC, 2004. The biodiversity of the Niger delta environment Niger Delta development commission master plan projects final report. Niger Delta Development Commission.

Nwilo, P.C. and O.T. Badejo, 2001. Impacts of Oil spill along the Nigerian Coast. Proceedings of the 1st International Congress on Petroleum Contaminated Soils, Sediments and Water, (PCSSW' 01), Imperial College, London, pp: 27-39.

Obire, O., D.C. Tamuno and S.A. Wemedo, 2003. Physico-Chemical quality of elechi creek in port Harcourt, Nigeria. J. Applied Sci. Environ. Manage., 9: 79-84.

Odeyemi, O. and A.O. Ogunseitan, 1985. Petroleum industry and its pollution potential in Nigeria. Oil Petroleum Pollut., 2: 223-229. DOI: 10.1016/S0143-7127 (85)90218-2

Odokuma, L.O. and A.A. Dickson, 2003. Bioremediation of a crude oil polluted tropical mangrove environment. J. Applied Sci. Environ. Manage., 7: 23-29. 
Odu, C.T.I., 1972. Microbiology of soils contaminated with petroleum hydrocarbon extent of contamination and some soil and microbial properties affected after contamination. J. Institute Petroleum (London) 58: 201-208.

Odu, C.T.I., 1978. The effect of nutrient application and aeration on oil degradation in soil. Environ. Pollu., 15: 235-240. DOI: 10.1016/0013-9327 (78)900691

Ogbeibu, A.E. and R. Victor, 1989. The effects of road and bridge construction on the bank-root macrobenthic invertebrates of a Southern Nigeria Stream. Environ. Pollu., 56: 85-100. PMID: 15092480

Omoigberale, M. O. and A.E. Ogbeibu, 2005. Assessing the environmental impacts of oil exploration and production on the osse river, southern Nigeria: Heavy metals. Afr. J. Environ. Pollute. Health, 4: 27-32.

Robertson, A.I. and D.M. Alongi, 1995. Role of riverine mangrove forests in organic carbon export to the tropical coastal ocean: A preliminary mass balance for the Fly Delta (Papua New Guinea). Geo-Marine Lett., 15: 134-139. DOI: 10.1007/BF01204454

Snedaker, S.C. and J.G. Snedaker, 1984. The Mangrove Ecosystem: Research Methods. 1st Edn., UNESCO, Paris, ISBN-10: 9231021818, pp: 251.
Suni, S., K. Koskinen, S. Kauppi, E. Hnnula ans T. Ryynanen et al., 2007. Removal by sorption and in-situ biodegradation of Oil spills limits damage to Marine Biota: laboratory Simulation. Ambio, 36: 173-179. PMID: 17520931

Tomlinson, P.B., 1986. Traditional and Medicinal Uses Of Mangroves. In: The Botany of Mangroves, Ashton P.S., S.P. Hubbel, D.H. Janzen and P.O.H.R. Tomlinson, (Eds.). Cambridge University Press, New York, U.S.A., pp: 133-148.

Vandermeulen, J.H. and E.S. Gilfillan, 1985. Petroleum, Pollution, corals and mangroves. Marine Technol. Soc. J., 18: 11-16.

Venosa, A.D., M.T. Suidan, B.A. Wrenn, K.L. Strohmeier and J.R. Haines et al., 1996. Bioremediation of an Experimental Oil Spill on the Shoreline of Delaware Bay. Environ. Sci. Technol., 30: 1764-1775. DOI: 10.1021/es950754r

Victor, R. and J.O. Tetteh, 1988. Fish Communities of a perturbed stream in Southern Nigeria. J. Tropical Ecology, 4: 49-59. DOI: $10.1017 / \mathrm{S} 0266467400002492$

Wilson, K., G. Sewell, J.A. Kean, and K. Vangelas 2007. Enhanced attenuation: Its place in the remediation of chlorinated solvents. Remediation, 17: 39-49. DOI: 10.1002/REM. 20123 